\title{
Pengaruh Kompetensi Kepribadian Guru terhadap Akhlak Siswa di SMK Cendekian Muslim Nanggung-Bogor
}

\author{
Evi Safitri ${ }^{1)}$, Yanti Hasbian Setiawati ${ }^{2)}$, Agus Suryana ${ }^{3)}$ \\ Fakultas Tarbiyah, IAI Nasional Laa Roiba Bogor \\ hasbianyantisetiawati@gmail.com ${ }^{1)}$ \\ suryaagus2012@gmail.com ${ }^{2)}$ \\ Evisaf23@gmail.com ${ }^{3)}$
}

\begin{abstract}
Abstrack
Islamic religious education teachers are often targeted and cornered when many students violate school rules and regulations. But with the personality competence of Islamic religious education teachers, students can imitate the attitudes and actions of their teachers. This research was conducted at SMK Cendikia Muslim Nanggung Bogor. The research population was 832 students while the sample was 40 students, with a stratified random sampling technique. This study applies the correlation method with research instruments using a questionnaire for the personality competence of Islamic religious education teachers and student morals using a questionnaire. The data were analyzed using the product moment correlation technique. The results showed that $r$ count $=0.731$, which means that there is an influence of the personality competence of Islamic religious education teachers on student morals. Likewise, the significance test with the $t$ test shows $t$ count $6.603 t$ table 2.024, this means that the influence of personality competences of Islamic religious education teachers has a significant effect. While the contribution of Islamic religious education teachers to student morals is shown by the coefficient of determination $=53 \%$ which means that the personality competence of Islamic religious education teachers makes a large contribution to student morals.
\end{abstract}

Keywords: Personality Competence Teacher, Islamic Education, Student Morals.

\begin{abstract}
Abstrak
Penelitian ini dilatarbelakangi oleh akhlak siswa yang semakin hari semakin menghawatirkan, dan meresahkan. Guru pendidikan agama islam sering menjadi sasaran dan terpojokkan saat banyak siswa yang melanggar peraturan dan tata tertib disekolah. Tetapi dengan kompetensi kepribadian guru pendidikan agama islam, siswa dapat mencontoh sikap dan perbuatan yang dilakukan oleh gurunya. Penelitian ini dilakkan di SMK Cendikia Muslim Nanggung Bogor. Populasi penelitian 832 siswa sedangkan sampelnya 40 siswa, dengan teknik stratified random sampling. Penelitian ini menerapkan metode korelasi dengan instrumen penelitian menggunakan angket untuk kompetensi kepribadian guru pendidikan agama islam dan akhlak siswa pun menggunakan angket. Data dianalisis menggunakan teknik korelasi product moment. Hasil penelitain menunjukkan $r$ hitung $=0,731$ yang berarti ada pengaruh kompetensi kepribadian guru pendidikan agama islam terhadap akhlak siswa. Begitu juga uji signifikasi dengan uji t memperlihatkan thitung 6,603 > t tabel 2,024 ini berarti pengaruh kompetensi kepribadian guru pendidikan agama islam memiliki pengaruh yang signifikan. Sedangkan kontribusi guru pendidikan agama islam terhadap akhlak siswa ditunjukkan oleh koefisien determinasi $=53 \%$ yang bermakna bahwa kompetensi kepribadian guru pendidikan agama islam memberikan kontribusi besar terhadap akhlak siswa.
\end{abstract}

Kata kunci : Kompetensi Kepribadian Guru, Pendidikan Agama Islam, Akhlak Siswa. PENDAHULUAN sebagai bagian terpenting dalam proses

Pendidikan merupakan salah satu cara untuk mendapatkan pengetahuan. Pendidikan juga dikatakan pertumbuhan dan perkembangan manusia, dengan adanya pendidikan manusia dapat mengetahui tujuan hidup 
yang ingin dicapainya. Dan dengan pendidikan pula manusia dapat menjadi manusia yang unggul serta kreatif.

Proses pendidikan di Indonesia tidak terlepas dari kegiatan belajar mengajar. Kegiatan belajar mengajar bertujuan bukan hanya sebagai suatu pemindahan ilmu pengetahuan dari seorang guru kepada siswanya tetapi untuk menteransfer sikap-sikap baik seorang guru kepada seorang siswa. Pendidikan pula dapat mencerdaskan dan memajukan kehidupan bangsa Indonesia ini. Dalam prosesnya di kelas pendidikan harus membangun akhlak siswanya.

Sekolah merupakan suatu lembaga pendidikan formal tempat berlangsungnya kegiatan belajar mengajar. Di sekolah seorang guru menjadi orangtua bagi siswanya. Seorang guru memberikan ilmu pengetahuan, nilai-nilai keagamaan serta mengajarkan akhlak-akhlak terpuji kepada siswa nya akhlak-akhlak terpuji kepada siswanya. Agar siswa menjadi pribadi yang baik, pribadi yang unggul, terampil dan mandiri.

Guru merupakan panutan siswa saat mereka berada disekolah. Guru memegang peran yang sangat penting dalam kegiatan belajar mengajar. Apa yang dilakukan seorang guru akan menjadi contoh bagi perilaku siswanya. Karena itu, untuk menjadi seorang guru harus memiliki kemampuan dan keahlian. Tidak semua orang dapat menjadi seorang guru, karena itu menjadi seorang guru harus memiliki berbagai kompetensi atau keahlian di bidang pendidikan. Salah satu kompetensi yang harus dimiliki seorang guru adalah kompetensi kepribadian. Kompetensi kepribadian seorang guru sangatlah penting, kompetensi kepribadian ini diharapkan mampu memberikan efek positif kepada siswanya. Seperti firman Allah yang dijelaskan dalam Al-Qur'an Surat Ar Rahman ayat 1-4 yaitu :

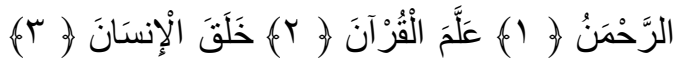

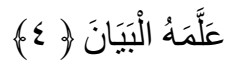

$$
\begin{aligned}
& \text { Artinya : Tuhan yang Maha } \\
& \text { Pemurah, yang telah mengajarkan } \\
& \text { Al.Qur'an, Dia menciptakan manusia, }
\end{aligned}
$$


disimpulkan bahwa seorang guru harus memiliki sifat (rahman) atau rasa kasih sayang dalam mendidik siswanya, serta menyayangi semua siswanya tanpa membedakan antara siswa yang baik atau siswa yang nakal, serta lemah lembut dan sabar dalam memberikan pengajaran kepada siswanya. Sehingga rasa kasih sayang tersebut dapat menjadikan dirinya sebagai sosok yang meneladani Allah dalam melaksanakan pendidikan serta memberikan efek yang positif kepada siswanya.

Akhlak menjadi bagian terpenting dalam kehidupan, karena akhlak dapat dijadikan sebagai tanda apakah seseorang itu bersifat baik atau bersifat buruk. Dalam kegiatan belajar mengajar Pendidikan Agama Islam tidak akan terlepas dari nilai-nilai akhlak. Pendidikan akhlak menjadi bagian terpenting dalam kehidupan sehari-hari, karena dengan akhlak yang baik siswa dapat menegakkan nilainilai ajaran agama yang mulia dan benar serta dapat meniru akhlak-akhlak baik Rasulullah saw.

Dalam pendidikan akhlak orangtua dan keluarga mempunyai tanggungjawab yang besar, karena dari keluargalah siswa mendapatkan pendidikan akhlak untuk pertama kali.
Begitu pun dengan disekolah tempat mereka menuntut ilmu, pendidikan akhlak akan dikembangkan.

Pendidikan akhlak seharusnya tidak hanya di fokuskan pada pelajaran agama saja, tapi pada pelajaran lainnya juga. Sekolah negeri ataupun sekolah swasta harus bisa mewujudkan perilaku siswanya berakhlakul karimah melalui semua pelajaran dan extrakulikuler yang berpendidikan karakter. Karena guru, di gugu dan ditiru oleh siswanya. Jika semua elemen baik itu pihak sekolah, orangtua dan masyarakat bekerjasama dalam pembentukan akhlak seorang siswa atau seorang anak maka akan lebih mudah dan efektif akhlak positif itu akan tercapai. Kerjasama sekecil apapun dalam pembentukan akhlak siswa dapat berpengaruh dan sangat membantu dalam proses pendidikan akhlak. Karena pendidikan akhlak bukanlah sesuatu yang baru, sebenarnya pendidikan akhlak itu sudah di mulai sejak seorang anak berada dirumah.

Faktanya pada zaman sekarang ini terdapat banyak sekali siswa yang berperilaku tidak baik bahkan tidak sopan kepada guru dan orangtuanya, serta berbuat jahat kepada temannya. Kekerasan di dunia pendidikan pun masih banyak terjadi, seperti kekerasan 
terhadap seorang teman dikelas, kekerasan terhadap siswa yang berkebutuhan khusus bahkan kekerasan siswa terhadap guru atau pun kekerasan guru kepada siswa. Kasus-kasus seperti inilah yang membuat pendidikan di Indonesia seharusnya dapat menanamkan nilai-nilai akhlak dari sejanak dini dan dari keluarga sebagai lingkungan pertama yang dijumpai oleh anak.

Kekerasan di dunia pendidikan menjadi masalah yang sangat serius. Beberapa kejadian yang tidak baik sering kita temui disekolah, seperti siswa membolos saat jam pelajaran, membangkang dan melawan kepada guru, siswa merokok, melakukan tindakan pengejekan terhadap teman, minum minuman dan obat-obatan yang terlarang, tawuran dan melakukan kegiatan yang melanggar peraturan sekolah lainnya.

Di kabupaten Bogor Seperti baru baru ini terjadi tawuran usai jam sekolah di sekitaran PT Ciko, Kelurahan Cimahpar, Kecamatan Bogor Utara, sekitar pukul 18:30 WIB (Mul diakses 23 Januari 2020) Kasus tawuran di atas terjadi di luar jam sekolah, bahkan terjadi di tengah malam. Dalam hal seperti ini orangtua siswa tidak dapat menyalahkan guru ataupun pihak sekolah karena aksi tawuran terjadi di luar jam sekolah. Namun dampak negatif dari aksi tawuran tersebut membuat nama sekolah menjadi sorotan publik, bahkan menjadi perbincangan masyarakat.

Permasalahan akhlak seperti inilah yang sangat menghawatirkan dunia pendidikan di Indonesia dan menjadikan guru Pendidikan Agama Islam sangat disudutkan dan terpojokkan sebagai sasaran dari perilaku-perilaku siswanya dalam pembentukan Akhlak. Padahal pada dasarnya seorang guru telah berusaha maksimal dalam pembentukan Akhlak siswanya. Dengan segala kemampuan yang dimilikinya. Salah satu kemampuan yang harus dimiliki yaitu kompetensi kepribadian, karena kepribadian guru dapat menjadikan teladan bagi siswa-siswanya. Padahal sejati Pendidikan Agama Islam serta penanaman nilai-nilai Akhlak bukan saja di ajarkan disekolah tetapi harus ajarkan pula di rumah.

Kompetensi kepribadian guru sangat penting untuk dikembangkan, baik melalui pelatihan atau pembiasaan. Jika seorang guru sudah memiliki budaya baik seperti jujur, amanah, adil, 
disiplin, dan bertanggung jawab maka seorang guru dapat mencetak akhlak siswa yang baik pula. Dengan akhlak guru yang baik dapat meningkatkan kualitas akhlak siswa yang baik pula. Karena kepribadian guru yang baik akan membuat siswanya merasa terkesan dan melakukan hal-hal yang positif sesuai akhlak islami yang diajarkan gurunya. Berdasarkan masalah diatas tujuan yang ingin dicapai dalam penelitian ini adalah sebagai berikut Untuk mengetahui Kompetensi Kepribadian Guru Pendidikan Agama Islam di SMK Cendikia Muslim Desa

Parakanmuncang Kecamatan Nanggung Kabupaten Bogor, untuk mengetahui Akhlak Siswa di SMK Cendikia Muslim Desa Parakanmuncang Kecamatan Nanggung Kabupaten Bogor, untuk mengetahui apakah ada Pengaruh Kompetensi Kepribadian Guru Pendidikan Agama Islam Terhadap Akhlak siswa di SMK Cendikia Muslim Desa Parakanmuncang Kecamatan Nanggung Kabupaten Bogor.

\section{KAJIAN TEORI}

\section{Akhlak Siswa}

Kalimat Akhlak berasal dari bahasa arab, yaitu al-akhlaq. Al-akhlaq bentuk jamak dari khuluq yang bermakna tabiat, kebiasaan atau adab. Dalam Kamus Besar Bahasa Indonesia, kata akhlak diartikan sebagai budi pekerti atau kelakuan. Kata akhlak walaupun terambil dari bahasa Arab ( yang biasa berarti kan tabiat, kebiasaan, bahkan agama) kata seperti itu tidak ditemukan dalam Al-Qu'ran (Ahmad Hawassy, 2008).

Menurut Ibnu Maskawih Akhlak artinya keadaan jiwa seseorang yang mendorongnya untuk melakukan perbuatan-perbuatan tanpa melalui pertimbangan pikiran terlebih dahulu. Keadaan ini terbagi dua, ada yang berasal dari tabiat aslinya, ada pula yang diperoleh dari kebiasaan yang berulang-ulang. Boleh jadi pada mulanya tindakan itu melalui pikiran dan pertimbangan, kemudian dilakukan terus-menerus, maka jadilah suatu bakat dan akhlak (Rosihon Anwar, 2010).

Ulama akhlak menyatakan bahwa akhlak terbagi dua yaitu akhlak baik merupakan sifat para nabi dan orang-orang Shiddiq, sedangkan akhlak yang buruk merupakan sifat syaitan dan 
orang-orang yang tercela, dan akhlak terhadap lingkungan.

Ada beberapa faktor yang mempengaruhi pembentukan akhlak seseorang, yaitu : 1) faktor dari dalam yang bentuknya berupa kecenderungan, bakat, akal dan lain-lain, 2) faktor dari luar seperti lingkungan sosial, termasuk pembinaan dan pendidikan yang diberikan. 3) faktor internal dari pembawaan si anak dan faktor dari luar yaitu pendidikan dan pembinaan yang dibuat secara khusus melalui interaksi dalam lingkungan sosial.

\section{Kompetensi Kepribadian Guru Pendidikan Agama Islam}

Kompetensi adalah keahlian yang harus di miliki seorang guru. Keahlian seorang guru berbeda dengan keahlian yang lainnya, maka dari itu tidak semua orang mempunyai kemampuan seperti guru. Kepribadian adalah ciri, sifat dan kebiasaan seseorang yang membedakannya dengan yang lainnya. Kepribadian seseorang dapat dipengaruhi oleh keadaan emosi, keadaan sosial dan keadaan lingkungan.

Secara etimologis guru sering disebut pendidik. Dalam bahasa Arab, ada beberapa kata yang menunjukkan profesi ini seperti mudarris, mu'allim, murabbi, dan mu'addib, yang meski memiliki makna yang sama namun masing-masing mempunyai karakteristik yang berbeda. Disamping kata-kata tersebut, juga sering digunakan kata ustad atau syaikh (H.Ramayulis, 2016)

Kompetensi kepribadian merupakan kompetensi yang berkenaan dengan pengembangan pribadi yang beriman dan bertakwa kepada Tuhan Yang Maha Esa, berbudi pekerti luhur, berkepribadian mantap, mandiri, jujur, adil, perhatian, dan mempunyai rasa tanggung jawab kemasyarakatan dan kebangsaan.

Kepribadian lah yang akan menentukan seseorang dapat menjadi pendidik dan Pembina yang baik bagi anak didiknya, ataukah akan menjadi perusak atau penghancur masa depan anak didiknya, terutama bagi anak didik yang masih kecil siswa tingkat sekolah dasar dan mereka yang sedang mengalami kegoncangan jiwa siswa tingkat Sekolah Menengah titik guru yang baik menjadi sebuah kebutuhan dalam rangka membangun etika dan moral peserta didik. Guru yang baik senantiasa menjadi pilihan dan panutan peserta didik (Rulam Ahmadi, 2018) 
Pendidikan Islam adalah kegiatan yang dilakukan oleh pendidik dalam mengarahkan pertumbuhan dan perkembangan anak didik menjadi manusia dewasa sesuai dengan tujuan pendidikan islam. Pendidikan Islam merupakan proses yang harus dilakukan secara bekesinambungan, semenjak dalam kandungan ibu, usia dini, remaja, hingga usia lanjut (Hamdani Hamid dan Beni Ahmad Saebeni, 2013).

Kompetensi kepribadian guru Pendidikan Agama Islam adalah kompetensi yang berhubungan dengan kemampuan pribadi guru Pendidikan Agama Islam dengan segala ciri khas yang dimilikinya dan diharapkan dapat menanamkan nilai-nilai akhlak yang positif pada siswanya. Kompetensi kepribadian guru sangat penting, karena kepribadian guru sangat dijadikan contoh oleh peserta didiknya. Ciri khas pada kepribadian guru yang akan dicontoh oleh peserta didiknya seperti pribadi yang disiplin, pribadi jujur dan adil, pribadi berakhlak mulia, pribadi yang teladan, pribadi yang mantap dan stabil, pribadi yang arif dan penyabar, dan pribadi yang perhatian serta bertaqwa kepada Allah SWT. Mata pelajaran Pendidikan Agama Islam tidak akan terlepas dari sosok siapakah guru yang menyampaikan mata pelajaran tersebut, sehingga menjadi guru Pendidikan Agama Islam benarbenar memerlukan keahlian dan kemampuan yang baik.

Akhlak adalah suatu sikap, tabiat, perbuatan, perilaku, atau kebiasaan yang di timbulkan seseorang secara terus menerus dan menjadi ciri khasnya. Keadaan akhlak pada jiwa seseorang dapat berubah secara spontan sesuai dengan kekuatan jiwa yang mendorongnya untuk melakukan hal-hal itu tanpa dipertimbangkan. Dalam kehidupan sehari-hari disekolah siswa berinteraksi dengan guru dan temannya. Interakasi tersebut dapat berupa akhlak yang baik atau terpuji dan akhlak buruk atau tercela.

Penulis simpulkan bahwa kompetensi kepribadian guru adalah kompetensi yang berhubungan dengan sosok kepribadian guru. Kompetensi kepribadian guru tidak hanya dilihat saat seorang guru berada didalam kelas, tetapi kepribadian guru yang baik harus dapat dilihat walaupun seorang guru tidak sedang mengajar. Sehingga siswa dapat menyimpan kesan positif dari seorang guru walaupun siswa tersebut sedang berada diluar sekolah. 


\section{METODOLOGI PENELITIAN}

Tempat yang dijadikan lokasi penelitian adalah SMK Cendikia Muslim yang beralamat di Jln. Raya Ace Tabrani Kp. Lukut Desa Parakanmuncang Kecamatan Nanggung Kabupaten Bogor Provinsi Jawabarat. Waktu penelitian ini dilakukan pada bulan Maret 2020 sampai dengan bulan September tahun 2020. Waktu tersebut penulis gunakan untuk survei pendahuluan, mengambil data, melakukan analisis, dan menyusun laporan penelitian.

Metode penelitian pada dasarnya merupakan cara ilmiah untuk mendapatkan data dengan tujuan dan kegunaan tertentu. Berdasarkan hal tersebut terdapat empat kata kunci yang perlu diperhatikan yaitu, cara ilmiah, data, tujuan, dan kegunaan.

Metode merupakan cara utama yang digunakan untuk mencapai suatu tujuan penelitian titik berdasarkan judul penelitian yang akan diteliti yaitu pengaruh kompetensi kepribadian guru Pendidikan Agama Islam terhadap akhlak siswa di SMK Cendikia Muslim Jln. Raya Ace Tabrani Kp. Lukut Desa Parakanmuncang Kecamatan Nanggung Kabupaten Bogor Provinsi Jawabarat,maka dalam hal ini metode yang digunakan adalah metode deskriptif kuantitatif.

Metode kuantitatif dinamakan metode tradisional karena metode ini sudah cukup lama digunakan sehingga sudah mentradisi sebagai metode untuk penelitian.

Variabel penelitian adalah obyek yang mempunyai variasi antara satu orang dengan orang lain. Sedangkan Bohnstedts menyatakan bahwa variabel adalah karakteristik dari orang, objek, atau kejadian yang berbeda dalam nilainilai yang dijumpai pada orang, objek, atau kejadian itu. Variabel pada dasarnya yaitu suatu hal yang berbentuk apa saja yang ditetapkan oleh peneliti untuk dipelajari sehingga diperoleh informasi tentang hal tersebut, kemudian ditarik kesimpulan. Maka dari penelitian diatas penelitian ini mempunyai dua variabel yaitu : 1) Variabel Bebas atau Variabel Independen disebut dengan variabel $\mathrm{X}$ (Kompetensi Kepribadian Guru Pendidikan Agama Islam). Variabel ini merupakan variabel yang mempengaruhi atau menjadi sebab perubahannya atau timbulnya variabel dependen. 2) Variabel terikat atau Dependen disebut dengan variabel $\mathrm{Y}$ (Akhlak Siswa). Variabel terikat 
merupakan variabel yang dipengaruhi oleh variabel bebas. Variabel terikat merupakan variabel yang dipengaruhi atau yang menjadi akibat, karena adanya variabel bebas.

\section{Populasi dan Sampel Penelitian}

Populasi adalah keseluruhan elemen yang akan diteliti. Sementara menurut Sugiyono dalam mendefinisikan populasi sebagai wilayah generalisasi yang terdiri atas objek atau subjek yang mempunyai kualitas dan karakteristik tertentu yang ditetapkan oleh peneliti untuk dipelajari dan kemudian ditarik kesimpulannya. Adapun populasi dari penelitian ini adalah seluruh siswa SMK Cendikia Muslim Tahun Pelajaran 2020-2021 yang berjumlah 832 siswa. Sampel adalah sebagian dari populasi yang dimiliki sifat karakteristik yang sama sehingga betul betul mewakili populasi. Teknik yang digunakan dalam penelitan ini dengan teknik random sampling, yakni pengambilan secara acak dari jumlah populasi. Oleh karena itu, yang diambil dari jumlah populasi 40 siswa.

\section{Instrumen Penelitian}

Adapun instrumen penelitian yang digunakan untuk mengumpulkan data dalam kegiatan penelitian ini adalah menggunakan angket dengan skala pengukuran yaitu skala likert. Skala likert digunakan untuk mengukur sikap, pendapat, dan persepsi seseorang atau sekelompok orang tentang fenomena sosial.

Untuk memperoleh data-data lapangan ini penulis menggunakan angket, wawancara, observasi, dan dokumentasi. Angket penelitian ini adalah angket tertutup tentang kepribadian guru pendidikan agama islam dan akhlak siswa. Adapun observasi dilakukan untuk mengamati objek penelitian. Sedangkan wawancara dilakukan dengan kepala sekolah, dewan guru, dan siswa SMK Cendikia Muslim. Selain itu, penulis meneliti beberapa dokumen SMK Cendikia Muslim mulai sejarah didirikannya SMK Cendikia Muslim, profil sekolah, visi misi dan tujuan SMK Cendikia Muslim serta keadaan sarana dan prasarana juga data-data guru SMK Cendikia Muslim.

\section{Definisi Konseptual dan Operasional}

$$
\text { Kompetensi Kompetensi }
$$

kepribadian guru Pendidikan Agama Islam adalah kompetensi yang berhubungan dengan kemampuan pribadi guru Pendidikan Agama Islam dengan segala ciri khas yang dimilikinya dan diharapkan dapat 
menanamkan nilai-nilai akhlak yang positif pada siswanya. Kompetensi Kompetensi kepribadian guru Pendidikan Agama Islam adalah kompetensi yang berhubungan dengan kemampuan pribadi guru Pendidikan Agama Islam dengan segala ciri khas yang dimilikinya. Ciri khas pada kepribadian guru yang akan dicontoh oleh peserta didiknya seperti pribadi yang disiplin, pribadi yang jujur dan adil, pribadi berakhlak mulia, pribadi yang teladan, pribadi yang mantap dan stabil, pribadi yang arif dan penyabar serta pribdi yang perhatian. Akhlak adalah suatu sikap, tabiat, perbuatan, perilaku, atau kebiasaan yang di timbulkan seseorang secara terus menerus dan menjadi ciri khasnya. Akhlak adalah suatu sikap, tabiat, perbuatan, perilaku, atau kebiasaan yang di timbulkan seseorang secara terus menerus dan menjadi ciri khasnya. Keadaan akhlak pada jiwa seseorang dapat berubah secara spontan sesuai dengan kekuatan jiwa yang mendorongnya untuk melakukan hal-hal itu tanpa dipertimbangkan. Dalam kehidupan sehari-hari disekolah siswa berinteraksi dengan guru dan temannya. Interakasi tersebut dapat berupa akhlak yang baik atau terpuji dan akhlak buruk atau tercela.

Kisi-kisi Instrumen Penelitian

\begin{tabular}{|c|c|c|c|c|c|c|}
\hline Variabel & $\begin{array}{l}\text { Indikator } \\
\text { Atau aspek }\end{array}$ & $\begin{array}{l}\text { Pernyataan } \\
(+)\end{array}$ & $\begin{array}{l}\text { Pernyataan } \\
(-)\end{array}$ & + & - & Total \\
\hline \multirow{6}{*}{$\begin{array}{l}\text { Kompetensi } \\
\text { kepribadian } \\
\text { Guru } \\
\text { Pendidikan } \\
\text { Agama } \\
\text { Islam } \\
\text { (Variabel } \\
\mathrm{X} \text { ) }\end{array}$} & $\begin{array}{l}\text { 1. Pribadi yang } \\
\text { Disiplin }\end{array}$ & 1,2 & & 2 & & 2 \\
\hline & $\begin{array}{l}\text { 2. Pribadi yang } \\
\text { Jujur dan Adil }\end{array}$ & 3,21 & & 2 & & 2 \\
\hline & $\begin{array}{l}\text { 3. Pribadi } \\
\text { Berakhlak Mulia }\end{array}$ & $4,12,23$ & 14,22 & 3 & 2 & 5 \\
\hline & $\begin{array}{l}\text { 4. Pribadi } \\
\text { Teladan }\end{array}$ & $7,9,16,18,19$ & 6 & 5 & 1 & 6 \\
\hline & $\begin{array}{l}\text { 5. Pribadi yang } \\
\text { Mantap dan } \\
\text { Stabil }\end{array}$ & 15 & 11,17 & 1 & 2 & 3 \\
\hline & 6. Pribadi yang & 10,25 & 26 & 2 & 1 & 3 \\
\hline
\end{tabular}




\begin{tabular}{|l|l|l|l|l|l|c|}
\hline $\begin{array}{l}\text { Arif Dan } \\
\text { Penyabar }\end{array}$ & & & & & \\
\cline { 2 - 7 } & $\begin{array}{l}\text { 7. Pribadi yang } \\
\text { Perhatian }\end{array}$ & $5,13,24$ & 8,20 & 3 & 2 & 5 \\
\cline { 2 - 7 } & Jumlah & & & 18 & 8 & 26 \\
\hline
\end{tabular}

Kisi-kisi Instrumen Penelitian Akhlak Siswa

\begin{tabular}{|c|c|c|c|c|c|c|c|}
\hline Variabel & Indikator & Sub Indikator & $\begin{array}{l}\text { Pernyataan } \\
(+)\end{array}$ & $\begin{array}{l}\text { Pernyataan } \\
(-)\end{array}$ & + & - & Total \\
\hline \multirow[t]{3}{*}{$\begin{array}{l}\text { Akhlak } \\
\text { Siswa } \\
\text { (Variabel } \\
\text { Y) }\end{array}$} & $\begin{array}{l}\text { Akhlak } \\
\text { baik } \\
\text { terhadap } \\
\text { Tuhan }\end{array}$ & $\begin{array}{c}\text { Bertaubat, } \\
\text { Bersabar, } \\
\text { Bersyukur, } \\
\text { Bertawakkal, } \\
\text { Ikhlas,Raja', } \\
\text { Bersikap Takut }\end{array}$ & $1,2,19$ & 20,3 & 3 & 2 & 5 \\
\hline & $\begin{array}{l}\text { Akhlak } \\
\text { baik } \\
\text { terhadap } \\
\text { sesama } \\
\text { manusia }\end{array}$ & $\begin{array}{c}\text { Kasih } \\
\text { sayang,Rasa } \\
\text { persaudaraan, } \\
\text { Memberi } \\
\text { nasehat, } \\
\text { Memberi } \\
\text { pertolongan, } \\
\text { Menahan } \\
\text { amarah,Sopan } \\
\text { santun,Suka } \\
\text { memaafkan. }\end{array}$ & $\begin{array}{c}4,5,6,11,13, \\
14,15,16,17, \\
22\end{array}$ & $\begin{array}{c}7,8,9,10,18 \\
21,12\end{array}$ & 10 & 7 & 17 \\
\hline & $\begin{array}{l}\text { Akhlak } \\
\text { terhadap } \\
\text { lingkung } \\
\text { an }\end{array}$ & $\begin{array}{c}\text { Keimanan dan } \\
\text { Peribdatan, } \\
\text { Hubungan } \\
\text { Pemanfaatan, } \\
\text { Hubungan } \\
\text { Pemeliharaan. }\end{array}$ & $23,24,26$ & 25 & 3 & 1 & 4 \\
\hline
\end{tabular}




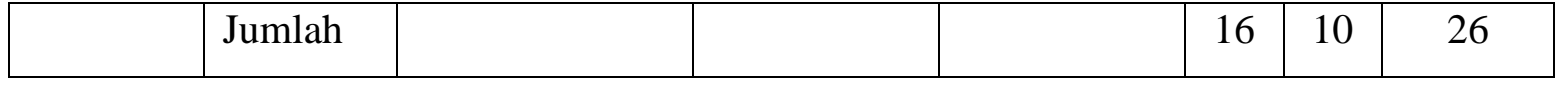

Uji instrument ini di lakukan untuk mengetahui tingkat validitas dan reliabilitas angket dalam penelitian.

\section{Uji Validitas}

Uji validitas adalah pengujian sejauh mana suatu alat ukur yang digunakan untuk mengukur tingkatantingkatan kevalidan atau kesohihahn suatu instrumen. Suatu instrument yang valid atau sahih memiliki validitas yang tinggi. Sebuah instrument dikatakan valid apabila mampu mengukur apa yang kita inginkan dan dapat mengungkap data dari variabel yang diteliti secara tepat. Cara pengujian validitas dengan menghitung korelasi antara skor masing-masing pertanyaanTeknik korelasi Product Moment ini di gunakan untuk mencari hubungan dan membuktikan hipotesis hubungan dua variabel bila data kedua variabel berbentuk interval atau ratio, dan sumber data dari dua variabel atau lebih tersebut adalah sama.Valid tidaknya suatu item instrument dapat di ketahui dengan membandingkan indeks Korelasi Product Moment atau $\mathrm{r}$ hitung dengan nilai kritisnya dan rumus
Product Moment yang digunakan adalah sebagai berikut:

$$
r x y: \frac{(N)\left(\sum X Y\right)-\left(\sum X\right)\left(\sum Y\right)}{\sqrt{\left\{(N)\left(\sum X^{2}\right)-\left(\sum X\right)^{2}\right\} \cdot\left\{(N)\left(\Sigma Y^{2}\right)-(\Sigma Y)^{2}\right\}}}
$$

Keterangan :

rxy : Angka indeks kolerasi " $\mathrm{r}$ "

product moment

$\mathrm{N}$ : Jumlah atau banyaknya sampel

$\sum X Y \quad$ Jumlah hasil perkalian tiap-tiap skor asli X dan Y

$\sum X \quad$ : Jumlah seluruh skor $\mathrm{X}$

$\sum Y \quad$ : Jumlah seluruh skor $\mathrm{Y}$

$\sum X^{2} \quad$ :Jumlah skor yang dikuadratkan dalam sebaran $\mathrm{X}$

$\sum Y^{2} \quad$ :Jumlah skor yang dikuadratkan dalam sebaran $\mathrm{Y}$

Uji validitas menunjukkan sejauh mana suatu instrument mengukur apa yang ingin diukur. Instrument di katakan valid apabila memiliki $\mathrm{r}>$ 0444, apabila harga koefisien korelasi di bawah 0,444 maka dapat di simpulkan bahwa butir instrument tersebut di katakan tidak valid.

Uji Validitas Variabel Kompetensi Kepribadian Guru Pendidikan Agama Islam (Variabel X)

\begin{tabular}{|c|c|c|c|c|}
\hline No Item & rhitung & rtabel & Validitas & Keputusan \\
\hline 1 & 0,444 & 0,315 & Invalid & Tidak Dipakai \\
\hline
\end{tabular}




\begin{tabular}{|c|c|c|c|c|}
\hline 2 & 0,444 & 0,534 & Valid & Dipakai \\
\hline 3 & 0,444 & 0,469 & Valid & Dipakai \\
\hline 4 & 0,444 & 0,519 & Valid & Dipakai \\
\hline 5 & 0,444 & 0,611 & Valid & Dipakai \\
\hline 6 & 0,444 & 0,198 & Invalid & Tidak Dipakai \\
\hline 7 & 0,444 & 0,638 & Valid & Dipakai \\
\hline 8 & 0,444 & 0,697 & Valid & Dipakai \\
\hline 9 & 0,444 & 0,474 & Valid & Dipakai \\
\hline 10 & 0,444 & 0,547 & Valid & Dipakai \\
\hline 11 & 0,444 & 0,556 & Valid & Dipakai \\
\hline 12 & 0,444 & 0,474 & Valid & Dipakai \\
\hline 13 & 0,444 & 0,182 & Invalid & Tidak Dipakai \\
\hline 14 & 0,444 & 0,533 & Valid & Dipakai \\
\hline 15 & 0,444 & 0,514 & Valid & Dipakai \\
\hline 16 & 0,444 & 0,532 & Valid & Dipakai \\
\hline 17 & 0,444 & 0,504 & Valid & Dipakai \\
\hline 18 & 0,444 & 0,455 & Valid & Dipakai \\
\hline 19 & 0,444 & 0,212 & Invalid & Tidak Dipakai \\
\hline 20 & 0,444 & 0,846 & Valid & Dipakai \\
\hline 21 & 0,444 & 0,188 & Invalid & Tidak Dipakai \\
\hline 22 & 0,444 & 0,596 & Valid & Dipakai \\
\hline 23 & 0,444 & 0,528 & Valid & Dipakai \\
\hline 24 & 0,444 & 0,566 & Valid & Dipakai \\
\hline 25 & 0,444 & 0,627 & Valid & Dipakai \\
\hline 26 & 0,444 & 0,029 & Invalid & Tidak Pakai \\
\hline
\end{tabular}

Dari data uji validitas dapat dikatan bahwa rhitung lebih besar dari $\mathrm{r}_{\text {tabel }}$ maka butir pertanyaan dianggap valid dan dapat digunakan sebagai sampel penelitian untuk mengetahui apakah ada pengaruh antara kompetensi kepribadian guru pendidikan agama islam terhadap akhlak siswa dengan sampel butir pertanyaan 26 butir soal.

Dari data uji validitas dapat dikatan bahwa rhitung lebih besar dari $\mathrm{r}_{\text {tabel }}$ maka butir pertanyaan dianggap valid dan dapat digunakan sebagai sampel penelitian untuk mengetahui 
apakah ada pengaruh antara kompetensi kepribadian guru pendidikan agama islam terhadap akhlak siswa dengan sampel butir pertanyaan 26 butir soal.

Berdasarkan hasil perhitungan data uji validitas, dapat disimpulkan bahwa hasil perhitungan $\mathrm{r}$ product moment dari 26 butir instrument dibandingkan dengan $r$ table didaptakan $r$ hitung > $r$ table, maka 21 instrument Akhlak Siswa dinyatakan valid dan dapat digunakan sebagai syarat uji instrumen penelitian.

\section{Uji Reliabilitas}

Realiabilitas adalah istilah untuk menunjukkan sejauh mana suatu hasil pengukuran relatif konsisiten atau dapat di percaya apabila pengukuran di ulangi dua kali atau lebih. Pengukuran reliabilitas bertujuan untuk mengetahui ketetapan suatu instrumen.

$r_{11}=\left(\frac{n}{n-1}\right)\left(\frac{S^{2}-\Sigma p q}{S^{2}}\right)$

Keterangan :

r11 : Reliabilitas tes secara keseluruhan

$\mathrm{p}$ : proporsi subjek yang menjawab benar butir soal ke-1

q : proporsi subjek yang menjawab salah butir soal ke-1 ( $q=1-p)$ $\mathrm{n}$ : Banyaknya item

S : Standar deviasi (akar varians)

Berikut adalah hasil uji Reliabilitas untuk Variabel Kompetensi Kepribadian Guru Pendidikan Agama islam :

\begin{tabular}{|c|c|}
\hline \multicolumn{2}{|c|}{ Reliability Statistics } \\
\hline $\begin{array}{c}\text { Cronbach's } \\
\text { Alpha }\end{array}$ & $\begin{array}{c}\text { N of } \\
\text { Item }\end{array}$ \\
\hline 0,87 & 20 \\
\hline
\end{tabular}

Berikut adalah hasil uji reliabilitas untuk Variabel Akhlak Siswa :

\begin{tabular}{|c|c|}
\hline \multicolumn{2}{|c|}{ Reliability Statistics } \\
\hline $\begin{array}{c}\text { Cronbach's } \\
\text { Alpha }\end{array}$ & $\begin{array}{c}\text { N of } \\
\text { Item }\end{array}$ \\
\hline 0,864 & 21 \\
\hline
\end{tabular}

Kesimpulan adalah jika alpa antara 0,70 - 0,90 maka Reliabilitas tinggi. Jika alpa 0,50- 0,70 maka Reliabilitas Moderat. Jika alpa $<0,50$ maka reliabilitas rendah. Jika alpa rendah, kemungkinan satu atau beberapa item tidak reliable. Dari data di atas, terlihat bahwa alpa 0,87 untuk variabel kompetensi kepribadian guru pendidikan agama islam dan 0,864 untuk variabel akhlak siswa. Maka reliabilitas tinggi dan instrumen 
dinyatakan reliable. Dengan demikian uji reliabilitas sebagai uji instrumen terpenuhi.

\section{Teknik Analisis Data}

Dalam analisis data tahapan yang dilakukan oleh peneliti yaitu analisis deskriptif yang terdiri dari menentukan rentang nilai teoritis dan rentang nilai empirik tiap variabel yang menggunakan angket, nilai rata-rata (Mean), dan standar deviasi dari variabel bebas dan variabel terikat, dan penyusunan tabel distribusi frekuensi dan analisis inferensial yaitu menganalisis korelasi antara variabel bebas dan variabel terikat dengan uji korelasi product moment.

Langkah-langkah yang dilakukan dalam analisis data, yaitu :

1. Teknik Analisis Data Deskriptif

Analisis deskriptif adalah teknik analisa yang memberikan informasi hanya mengenai data yang diamati dan tidak bertujuan menguji hipotesa serta menarik kesimpulan yang digeneralisasikan terhadap populasi. Langkah-langkah dalam analisis data deskriptif adalah sebagai berikut :

a. Menentukaan rentang skor teoritik dan rentang skor empirik.

b. Menentukan rata-rata (Mean)
Mencari mean menggunakan rumus : $\mathrm{Mx}=\frac{\sum \mathrm{x}}{N}$

Keterangan :

$\mathrm{Mx}=$ Mean yang dicari

$\sum \mathrm{x}=$ jumlah dari skor yang ada

$\mathrm{N}=$ banyak nya skor itu sendiri

c. Menentukan standar deviasi.

Dengan menggunakan rumus sebagai berikut :

$S D=\frac{\sqrt{\sum x^{2}}}{n-1}$

$\mathrm{SD}=$ Stadar Deviasi

$\sum x^{2}=$ Jumlah semua Deviasi

$\mathrm{N}$ = banyaknya skor itu sendiri

d. Menyusun distribusi frekuensi. Langkah-langkah yang harus dilakukan adalah sebagai berikut :

Langkah Pertama : mencari nilai tertinggi dan nilai terendah. Dengan rumus $\mathrm{R}=\mathrm{X} \max -\mathrm{X} \min$

Langkah kedua : menentukan banyaknya kelas dengan rumus $\mathrm{K}=1+$ 3,3 $\log n$

Langkah ketiga : menentuan panjang kelas. Dengan rumus $\mathrm{P}=\frac{R}{K}$

Langkah keempat : menentukan batas bawah dan batas atas kelas.

Langkah kelima : menghitung banyaknya data pada masing-masing kelas 
2. Analisis Inferensial

Penelitian ini menggunakan rumus korelasi product moment, yaitu analisis data untuk mengetahui pengaruh anatara variabel bebas dan variabel terikat, data untuk di uji hipotesis menggunakan rumus product moment, yaitu sebagai berikut :

rxy: $\frac{(N)\left(\sum X Y\right)-\left(\sum X\right)\left(\sum Y\right)}{\sqrt{\left\{(N)\left(\sum X^{2}\right)-\left(\sum X\right)^{2}\right\} \cdot\left\{(N)\left(\sum^{2}\right)-\left(\sum Y\right)^{2}\right\}}}$

Keterangan :

rxy : Angka indeks kolerasi "r" product moment

$\mathrm{N}$ : Jumlah atau banyaknya sampel

$\sum X Y \quad:$ Jumlah hasil perkalian tiap-tiap skor asli X dan Y

$\sum X \quad$ : Jumlah seluruh skor $\mathrm{X}$

$\sum Y \quad$ : Jumlah seluruh skor $\mathrm{Y}$

$\sum X^{2} \quad$ Jumlah skor yang dikuadratkan dalam sebaran $\mathrm{X}$

$\Sigma Y^{2}$ : Jumlah skor yang dikuadratkan dalam sebaran Y

a. Memberikan interprestasi terhadap angka indeks korelasi " $r$ " product moment terhadap angka indeks korelasi yang telah diperoleh dari perhitungan dapat diberikan interprestasi atau penafsiran tertentu.

b. Memberikan interprestasi terhadap angka indek korelasin"r" produc moment secara kasar (sederhana). Dalam memberikan interprestasi terhadap angka indeks. Korelasi " $r$ " product moment penulis menggunakan pedoman sebagai berikut

Pengukuran product moment

\begin{tabular}{|c|c|}
\hline $\begin{array}{c}\text { Interval } \\
\text { Koefisien }\end{array}$ & Tingkat hubungan \\
\hline $0,00-0,199$ & Sangat rendah \\
\hline $0,20-0399$ & Rendah \\
\hline $0,40,-0599$ & Sedang \\
\hline $0,60-0799$ & Kuat \\
\hline $0,80-1.000$ & Sangat kuat \\
\hline
\end{tabular}

c. Memberikan interprestasi terhadap angka indeks korelasi " $\mathrm{r}$ " produc moment, dengan jalan berkonsultasi pada table nilai "r" produc moment. Adapun langkah-langkah yang penulis lakukan sebagai berikut :

1) Merumuskan hipotesis alternative (Ho) dan hipotesis nihil (Ha) 2) Menguji kebenaran atau kepalsuan dari hipotesi yang telah diperoleh dalam perhitungan atau " $r$ " observasi (ro) dengan besarnya "r" yang tercantum dalam table nilai " $r$ " produc moment. Dengan terlebih dahul mencari derajat bebasnya $(\mathrm{db})$ atau degrees of freedomnya yang rumusnya sebagai berikut :

$$
\mathrm{Df}=\mathrm{N}-\mathrm{nr}
$$

Keterangan :

Df $=$ degrees of freedom 


$$
\begin{aligned}
& \mathrm{N}=\text { number of cases } \\
& \mathrm{Nr}=\text { banyaknya variabel }
\end{aligned}
$$

data yang dikorelasikan Dengan di peroleh db atau df maka dapat di cari besarnya "r" yang tercantum dalam table "r" produc moment, baik dalam tarap signifikan 5\% maupun pada taraf $1 \%$ jika $r_{o}$ sama dengan atau lebih besar dari $r_{t}$ maka hipotesis alternative (Ha) di setujui atau diterima atau terbukti kebenarannya. Berarti memang benar antara variabel $\mathrm{X}$ dan variabel $\mathrm{Y}$ terdapat korelasi yang signifikan. Sebaliknya hipotesis nihil (Ho) tidak terdapat disetujui atau tidak dapat di terima atau tidak terdapat terbukti kebenarannya, ini berarti hipotesis nihil yang mengatakan tidak adanya korelasi antara variabel $\mathrm{X}$ dengan $\mathrm{Y}$ itu salah. Sebaliknya jika $r_{o}$ itu kecil dari $r_{t}$ maka hipotesis alternative (Ha) di tolak dan hipotesis nihil diterima.

\section{HASIL DAN PEMBAHASAN}

\section{Hasil Penelitian}

Berdasarkan hasil data pengaruh kompetensi kepribadian guru pendidikan agama islam di dapatkan rentang skor empirik antara 43 sampai dengan 99 , dan rentang skor teoritik antara 20 sampai dengan 100, dengan skor tertinggi 99 dan skor terendah 43 dan standar devisiasi 39.

Tahapan dalam menyusun distribusi frekuensi, sebagai berikut :

a) Menentukan Mean Kompetensi Kepribadian Guru Pendidikan Agama Islam (MX)

$\mathrm{MX}=\frac{\sum x}{N}=\frac{3084}{40}=77,1$

b) Menentukan rentang ( $\mathrm{R})$ dengan nilai tertinggi dan nilai terendah.

$\mathrm{R}=\mathrm{X}_{\text {tertinggi }}-\mathrm{X}_{\text {terendah }}$

Skor tertinggi $=99$

Skor terendah $=43$

$\mathrm{R}=99-43=56$

c) Menentukan kelas interval

$\mathrm{K}=1+3,3 \log \mathrm{N}$

$\mathrm{K}=1+3,3 \log 40$

$\mathrm{K}=1+3,3(1,602)$

$\mathrm{K}=1+5,2866=6,2866$ (dibulatkan menjadi 6)

d) Panjang Kelas Interval

$\mathrm{P}=\frac{R}{K}=\frac{56}{6}=9,333$ (dibulatkan menjadi 10)

e) Menentukan tabel distribusi frekuensi, meiputi penentuan batas kelas bawah dan batas kelas atas, serta menghitung banyaknya data pada masing-masing kelas. 
Distribusi Frekuensi Kompetensi

Kepribadian Guru PAI

\begin{tabular}{|c|c|c|}
\hline Interval & Frekuensi & Presentase \\
\hline $43-52$ & 1 & $2,5 \%$ \\
\hline $53-62$ & 5 & $12,5 \%$ \\
\hline $63-72$ & 10 & $25 \%$ \\
\hline $73-82$ & 12 & $30 \%$ \\
\hline $83-92$ & 7 & $17,5 \%$ \\
\hline $93-102$ & 5 & $12,5 \%$ \\
\hline Jumlah & $\mathbf{4 0}$ & $\mathbf{1 0 0 \%}$ \\
\hline
\end{tabular}

Sedangkan berdasarkan hasil data akhlak siswa didapatkan rentang skor empirik antara 48 sampai dengan 97, dan rentang skor teoritis antara 20 sampai dengan 100, dengan skor tertinggi 97 dan skor terendah 48 dan standar devisiasi 41.

Tahapan dalam menyusun distribusi frekuensi, sebagai berikut :

a) Menentukan Mean Akhlak Siswa

$\mathrm{MX}=\frac{\sum x}{N}=\frac{3095}{40}=77,37$

b) Menentukan rentang (R) dengan nilai tertinggi dan nilai terendah.

$\mathrm{R}=\mathrm{X}_{\text {tertinggi- }} \mathrm{X}_{\text {terendah }}$
Skor tertinggi $=97$

Skor terendah $=48$

$R=97-48=49$

c) Menentukan kelas interval

$\mathrm{K}=1+3,3 \log \mathrm{N}$

$\mathrm{K}=1+3,3 \log 40$

$\mathrm{K}=1+3,3(1,602)$

$\mathrm{K}=1+5,2866=6,2866$ (dibulatkan menjadi 6)

d) Panjang Kelas Interval

$\mathrm{P}=\frac{R}{K}=\frac{49}{6}=8,167$ (dibulatkan menjadi

9)

e) Menentukan tabel distribusi frekuensi, meiputi penentuan batas kelas bawah dan batas kelas atas, serta menghitung banyaknya data pada masing-masing kelas.

Distribusi Frekuensi Akhlak Siswa

\begin{tabular}{|c|c|c|}
\hline Interval & Frekuensi & Presentase \\
\hline $48-56$ & 4 & $10 \%$ \\
\hline $57-65$ & 5 & $12,5 \%$ \\
\hline $66-74$ & 5 & $12,5 \%$ \\
\hline $75-83$ & 10 & $25 \%$ \\
\hline $84-92$ & 13 & $32,5 \%$ \\
\hline $93-101$ & 3 & $7,5 \%$ \\
\hline Jumlah & $\mathbf{4 0}$ & $\mathbf{1 0 0 \%}$ \\
\hline
\end{tabular}

Hasil Korelasi Kompetensi Kepribadian Guru Pendidikan Agama Islam Terhadap Akhlak Siswa

\begin{tabular}{|c|c|c|c|c|c|}
\hline No Responden & $\mathbf{X}$ & $\mathbf{Y}$ & $\mathbf{X Y}$ & $\mathbf{X}^{\mathbf{2}}$ & $\mathbf{Y}^{\mathbf{2}}$ \\
\hline 1 & 87 & 64 & 5568 & 7569 & 4096 \\
\hline
\end{tabular}




\begin{tabular}{|c|c|c|c|c|c|}
\hline 2 & 84 & 91 & 7644 & 7056 & 8281 \\
\hline 3 & 76 & 97 & 7372 & 5776 & 9409 \\
\hline 4 & 83 & 90 & 7470 & 6889 & 8100 \\
\hline 5 & 65 & 74 & 4810 & 4225 & 5476 \\
\hline 6 & 72 & 90 & 6480 & 5184 & 8100 \\
\hline 7 & 89 & 83 & 7387 & 7921 & 6889 \\
\hline 8 & 82 & 78 & 6396 & 6724 & 6084 \\
\hline 9 & 63 & 70 & 4410 & 3969 & 4900 \\
\hline 10 & 81 & 86 & 6966 & 6561 & 7396 \\
\hline 11 & 99 & 96 & 9504 & 9801 & 9216 \\
\hline 12 & 68 & 66 & 4488 & 4624 & 4356 \\
\hline 13 & 59 & 48 & 2832 & 3481 & 2304 \\
\hline 14 & 60 & 56 & 3360 & 3600 & 3136 \\
\hline 15 & 58 & 58 & 3364 & 3364 & 3364 \\
\hline 16 & 89 & 89 & 7921 & 7921 & 7921 \\
\hline 17 & 67 & 70 & 4690 & 4489 & 4900 \\
\hline 18 & 62 & 61 & 3782 & 3844 & 3721 \\
\hline 19 & 81 & 87 & 7047 & 6561 & 7569 \\
\hline 20 & 80 & 89 & 7120 & 6400 & 7921 \\
\hline 21 & 79 & 79 & 6241 & 6241 & 6241 \\
\hline 22 & 96 & 85 & 8160 & 9216 & 7225 \\
\hline 23 & 43 & 50 & 2150 & 1849 & 2500 \\
\hline 24 & 61 & 62 & 3782 & 3721 & 3844 \\
\hline 25 & 81 & 82 & 6642 & 6561 & 6724 \\
\hline 26 & 95 & 85 & 8075 & 9025 & 7225 \\
\hline 27 & 82 & 74 & 6068 & 6724 & 5476 \\
\hline 28 & 99 & 91 & 9009 & 9801 & 8281 \\
\hline 29 & 70 & 52 & 3640 & 4900 & 2704 \\
\hline 30 & 68 & 76 & 5168 & 4624 & 5776 \\
\hline 31 & 93 & 97 & 9021 & 8649 & 9409 \\
\hline 32 & 83 & 79 & 6557 & 6889 & 6241 \\
\hline
\end{tabular}




\begin{tabular}{|c|c|c|c|c|c|}
\hline 33 & 78 & 72 & 5616 & 6084 & 5184 \\
\hline 34 & 83 & 84 & 6972 & 6889 & 7056 \\
\hline 35 & 82 & 77 & 6314 & 6724 & 5929 \\
\hline 36 & 82 & 79 & 6478 & 6724 & 6241 \\
\hline 37 & 82 & 83 & 6806 & 6724 & 6889 \\
\hline 38 & 71 & 85 & 6035 & 5041 & 7225 \\
\hline 39 & 75 & 80 & 6000 & 5625 & 6400 \\
\hline 40 & 76 & 80 & 6080 & 5776 & 6400 \\
\hline Jumlah & $\mathbf{3 0 8 4}$ & $\mathbf{3 0 9 5}$ & $\mathbf{2 4 3 4 2 5}$ & $\mathbf{2 4 3 7 4 6}$ & $\mathbf{2 4 6 1 0 9}$ \\
\hline
\end{tabular}

Setelah diketahui data kedua variabel, maka tahap selanjutnya adalah pergolongan kedalam rumus product moment dengan keterangan sebagai berikut :

Keterangan yang diketahui pada Rumus Korelasi

\begin{tabular}{|l|l|l|l|l|l|}
\hline $\mathbf{N}$ & $\sum \mathbf{X}$ & $\sum \mathbf{Y}$ & $\sum \mathbf{X Y}$ & $\sum \mathbf{X}^{\mathbf{2}}$ & $\sum \mathbf{Y}^{\mathbf{2}}$ \\
\hline 4 & 308 & 309 & 2432 & 2437 & 2461 \\
0 & 4 & 5 & 25 & 46 & 09 \\
\hline
\end{tabular}

Penentuan hasil koefisien korelasi antara variabel $\mathrm{X}$ dan variabel $\mathrm{Y}$, maka perhitungan koefisien sebagai berikut :

$$
\begin{aligned}
& \text { rxy: } \frac{(N)\left(\sum X Y\right)-\left(\sum X\right)\left(\sum Y\right)}{\sqrt{\left\{(N)\left(\sum X^{2}\right)-\left(\sum X\right)^{2}\right\} \cdot\left\{(N)\left(\Sigma Y^{2}\right)-\left(\sum Y\right)^{2}\right\}}} \\
& \text { rxy: } \frac{(40)(243225)-(3084)(3095)}{\sqrt{\left\{(40)(243746)-(3084)^{2}\right\} \cdot\left\{(40)(246109)-(3095)^{2}\right\}}} \\
& \text { rxy: } \frac{9729000-9544980}{\sqrt{\{9749840}-9511056\} \cdot\{9844360-9579025\}}
\end{aligned}
$$

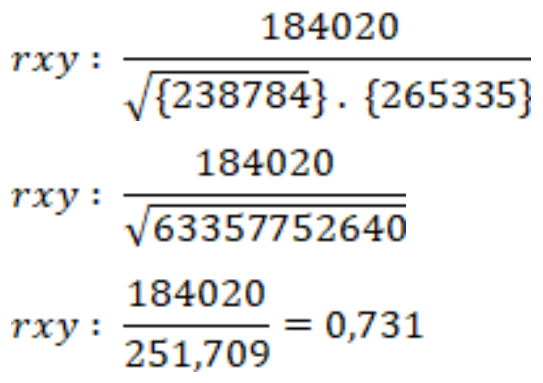

Dari perhitungan diatas dapat dilihat bahwa angka korelasi variabel Kompetensi Kepribadian Guru Pendidikan Agama Islam Terhadap Akhlak Siswa adalah 0,731. Jika nilai korelasi ditafsirkan dengan interpretasi berikut maka termasuk korelasi tingkat pengaruh kuat antara variabel $\mathrm{X}$ dan variabel Y.

Tabel 4.1 Interpretasi Data

\begin{tabular}{|l|l|}
\hline $\begin{array}{l}\text { Interval } \\
\text { Koefisien }\end{array}$ & $\begin{array}{l}\text { Interpretasi } \\
\text { Tingkat } \\
\text { Hubungan }\end{array}$ \\
\hline $0,00-0,199$ & Sangat rendah \\
\hline $0,20-0,399$ & Rendah \\
\hline $0,40-0,599$ & Sedang \\
\hline
\end{tabular}


50 | Transformasi Manageria, Vol. 1, No. 1, Juni 2021

\begin{tabular}{|l|l|}
\hline $0,60-0,799$ & Kuat \\
\hline $0,80-1,000$ & Sangat Kuat \\
\hline
\end{tabular}

Pengujian hipotesis juga

dilakukan dengan membandingkan

$r_{\text {hitung dengan }} r_{\text {tabel }}$. Penentukan $r_{\text {tabel }}$

harus di ketahui terlebih dahulu df atau

degree of freedom (derajat kebebasan)

yang nantinya akan di pergunakan

untuk mencari $\mathrm{r}_{\text {tabel. }}$ Untuk mencari df,

perhitungannya adalah sebagai berikut :

$$
\text { df } \quad \begin{aligned}
= & N-2 \\
& =40-2 \\
& =38
\end{aligned}
$$

Nilai df yaitu 38 dengan taraf kepercayaan (signifikan) 5\% maka di peroleh nilai $\mathrm{r}_{\text {tabel }}$ yaitu didapat 0,731 . Hasil pencarian tabel tersebut dimasukkan ke rumus hipotesis. Hasil perhitungan yang didapat $0,731>0,320$ atau $r_{\text {hitung }}>r_{\text {tabel }}$, artinya Ha diterima dan Ho ditolak. Maka dapat di simpulkan bahwa terdapat pengaruh yang signifikan antara Kompetensi Kepribadian Guru Pendidikan Agama Islam dengan Akhlak Siswa.

\section{Uji Signifikan}

Untuk menguji signifikasi data digunakan rumus hitung sebagai berikut:

$$
\mathrm{t}_{\text {hitung }}=\frac{r \sqrt{n-2}}{\sqrt{1-r^{2}}}
$$

$$
\begin{aligned}
&= \frac{0,731 \sqrt{ } 40-2}{\sqrt{1-(0,731)^{2}}} \\
&= \frac{0,731 \sqrt{ } 38}{\sqrt{1-0,534361}} \\
&= \frac{0,731 \times 6,164}{\sqrt{0.465639}} \\
&= 4.505884 \\
& 0,682377 \\
&=6,603
\end{aligned}
$$

Jika dikonsultasikan dengan $t_{\text {tabel }}$ dengan df (Degree of freedom) atau derajat kebebasan $=38$, taraf signifikan 0,05 maka di peroleh $\mathrm{t}$ tabel $=2,024$. Dengan demikian $t_{\text {hitung }}>t_{\text {tabel }}(6,603>$ 2,024). Dari perbandingan kedua nilai tersebut menunjukkan adanya pengaruh kompetensi kepribadian guru pendidikan agama islam dengan kategori kuat, hal ini ditunjukkan oleh tabel interpretasi.

\section{Uji Determinasi}

Untuk menyatakan besar kecilnya pengaruh antara variabel $\mathrm{X}$ dan variabel $\mathrm{Y}$, dinyatakan dalam koefisien determinan :

$$
\begin{aligned}
\mathrm{KD} & =\left(\mathrm{r}_{\mathrm{xy}}\right)^{2} \times 100 \% \\
& =(0,731)^{2} \times 100 \% \\
& =0,534361 \times 100 \% \\
& =53,4361 \%=53 \%
\end{aligned}
$$

Dari hasil perhitungan diatas menunjukkan bahwa Akhlak Siswa dipengaruhi oleh Kompetensi 
51 | Transformasi Manageria, Vol. 1, No. 1, Juni 2021

Kepribadian Guru Pendidikan Agama Islam sebesar $53 \%$ sedangkan sisanya ditentukan oleh faktor lainnya.

\section{Pembahasan}

Berdasarkan hasil analisis data dalam penelitian ini diketahui bahwa rata-rata skor Kompetensi Kepribadian Guru PAI sebesar 77,1 sedangkan ratarata Akhlak Siswa 77,37.

Dari hasil perhitungan koefisien korelasi Pearson Product Moment di peroleh $r$ hitung 0,731 sedangkan $r$ tabel 0,320. Begitu juga dengan menggunakan tabel interpretasi koefisien korelasi r hitung 0,731 masuk kategori kuat.

Mengingat $r$ hitung $0,731>r$ tabel 0,320 dapat disimpulkan terdapat pengaruh antara Kompetensi Kepribadian Guru Pendidikan Agama Islam Terhadap Akhlak Siswa dengan kategori kuat yang dilihat dari tabel interpretasi. Hal ini menunjukkan bahwa Kompetensi Kepribadian Guru Pendidikan Agama Islam sangat berpengaruh terhadap Akhlak Siswa. Temuan tersebut sejalan dengan konsep yang mengungkapkan bahwa kompetensi kepribadian guru adalah salah satu unsur yang sangat menentukan keakraban hubungan guru dengan anak didik. Kepribadian guru akan tercermin dalam sikap dan perbuatannya, dalam membina dan membimbing anak didiknya. Sikap dan perbuatan seorang guru mejadi unsur yang sangat penting dalam kompetensi kepribadian guru (Chaerul Rahman dan Heri Gunawan, 2017)

Sebagai teladan, guru harus memiliki kepribadian yang dapat dijadikan idola. Seluruh kehidupannya adalah figur yang paripurna, karena kepribadian guru memiliki andil yang sangat besar terhadap keberhasilan pendidikan, khususnya dalam kegiatan pembelajaran. Pribadi guru sangat berperan dalam membentu pribadi siswa. Hal ini tentu sangat dapat dimaklumi, karena manusia merupakan makhluk yang suka mencontoh, termasuk mencontoh pribadi gurunya dalam membentu pribadinya (Chaerul Rahman dan Heri Gunawan, 2017).

Tugas seorang guru adalah sebagai pendidik dan pengajar. Sebagai seorang pendidik, guru mentransfer nilai (transfer of value) dengan harapan peserta didiknya menjadi pribadi yang berkarakter. Kemudian sebagai seorang pengajar, guru mentransfer pengetahuan (transfer of knowledge) dan keterampilan (transfer of skill) agar peserta didik menguasai berbagai ilmu 
pengetahuan serta mampu mengaplikasikannya dalam kehidupan sehari-hari (Novan Ardy Wiyani, 2015)

Selain itu berdasarkan hasil wawancara dengan kepala sekolah SMK Cendikia Muslim mengakui bahwa untuk materi ajar, pengalaman dan segala macam nya sudah tidak perlu diragukan lagi. Karena guru Pendidikan Agama Islam SMK Cendikia Muslim sudah lama mengajar disekolahan tersebut. Selain itu guru Pendidikan Agama Islam juga rutin mengadakan kegiatan keagamaan untuk memotivasi siswa dalam beribadah, berbuat baik, juga adanya keterbukaan dalam berkomunikasi antara guru Pendidikan Agama Islam dengan siswa SMK Cendikia Muslim sehingga membuat siswa tidak ragu lagi untuk menyampaikan pendapat.

Guru Pendidikan Agama Islam juga menjadi pribadi yang mencerminkan kesederhanaan, selain itu dengan gaya bicara yang sopan, santun dan halus membawa pengaruh yang sangat baik untuk akhlak siswanya. Sehingga akhlak siswa di SMK Cendikia Muslim tergolong baik.

\section{KESIMPULAN}

Berdasarkan penelitian yang telah dilaksanakan Tentang Pengaruh Kompetensi Kepribadian Guru Pendidikan Agama Islam terhadap Akhlak Siswa di SMK Cendikia Musim Parakan Muncang Nanggung Bogor. Maka penulis dapat menarik beberapa kesimpulan : 1) Akhlak siswa di SMK Cendikia Muslim Parakan Muncang Nanggung Bogor nilai rata-ratanya adalah sebesar 77,37. 2) Kompetensi Kepribadian Guru Pendidikan Agama Islam di SMK Cendikia Muslim Parakan Muncang Nanggung Bogor nilai rata-ratanya adalah sebesar $77,1.3$ ) Ada pengaruh antara kompetensi kepribadian guru pendidikan agama islam terhadap akhlak siswa di SMK Cendikia Muslim Parakan Muncang Nanggung Bogor. Berdasarkan hasil analisis data menyatakan bahwa hasil pengujian koefisien korelasi Pearson Product Moment diperoleh rhitung = 0,731 sedangkan rtabel $=0,320$. Dengan demikian nilai rhitung > rtabel yakni 0,731>0,320. Maka jika dilihat dengan menggunakan tabel interpretasi koefisien korelasi rhitung 0,731 masuk pada kategori pengaruh yang kuat.

Selanjutnya berdasarkan hasil uji signifikan diperoleh thitung $=6,603$ 
yang dikonsultasikan dengan ttabel dengan df (Degree of Freedom) atau derajat kebebasan $=38$, taraf signifikan 0,05 maka diperoleh nilai ttabel 2,024. Dengan demikian nilai thitung $>$ ttabel yakni 6,603 > 2,024 perbandingan ini menunjukkan hasil yang signifikan, atau dengan kata lain ada pengaruh yang signifikan antara variabel kompetensi kepribadian guru pendidikan agama islam terhadap akhlak siswa.

Adapun besar kontribusi kompetensi kepribadian guru pendidikan agama islam terhadap akhlak siswa sebesar 53\% selebihnya dipengaruhi oleh faktor-faktor yang lainnya.

\section{DAFTAR PUSTAKA}

Ahmadi, Rulam, Profesi Keguruan Konsep \& Strategi Mengembangkan Profesi Karier Guru, (Yogyakarta : Ar Ruzz Media, 2018).

Anwar, Rosihon, Akhlak Tasawuf, (Bandung : CV Pustaka Setia,2010)

Hamid, Hamdani dan Beni Ahmad Saebeni, Pendidikan Karakter Persfektif Islam, (Bandung : CV Pustaka Setia, 2013).

Hawassy, Ahmad, Kajian Akhlak Dalam Bingkai Aswaja, Tanggerang : Genggambook epublisher,2008).
Mul, "Biang Tawuran Kini Bertangan Buntung", www.Metropolitan.id, diakses 23 Januari 2020.

Ramayulis, Bimbingan Konseling Islam Di Madrasah dan Sekolah, (Jakarta : Kalam Mulia, 2016).

Rochman, Chaerul dan Heri Gunawan, Pengembangan Kompetensi Kepribadian Guru, (Bandung : Penerbit Nuansa Cendikia, 2017).

Wahab, Rohmalina, Psikologi Belajar, Depok : PT. Raja Grafindo Persada, 2015).

Wiyani,Ardi, Novan, Etika Profesi Keguruan, (Yogyakarta : Penerbit Gava Media, 2015). 